\title{
Law, Business Strategy, And Social Change In The Global Environment
}

Evan A. Peterson, University of Detroit Mercy, USA

Carletta E. Griffin, D.M., University of Detroit Mercy, USA

Gregory W. Ulferts, DBA., University of Detroit Mercy, USA

Terry L. Howard, University of Detroit Mercy, USA

\begin{abstract}
In this article, we examine the dynamic relationship between law, economics, and sustainability. Increased legal regulation is not a sufficient condition for the mitigation of economic and social crises. Corporations are not legally required to respect global social and human rights under international law. In addition, select legal regulations increase social harm through the preservation of corporate financial interests. Laws that attempt to protect social rights at the expense of corporate interests can provoke hostile reactions from the business community. However, recent trends and examples from within the pharmaceutical and information industries suggest a new era of global corporate citizenship where socially responsible organizations achieve profit through pursuing ethical goals.
\end{abstract}

Keywords: Business Strategy; Globalization; Human Rights; Law, Social Change

\section{INTRODUCTION}

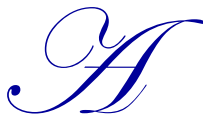

midst the exponential commercial growth shaped by globalization in recent years, governments, scholars, and the public have struggled to understand and manage the social impact of global corporate activities. The connections between economic policies, legal regulations, corporate activities, and social harms are now at the center of intense regional, national, and global debates. Unfortunately, the current foundations for corporate social responsibility (CSR) rest solely on organizational voluntary compliance (Muchlinksi, 2012). In response, George (2014) and other scholars advocate for dramatic increases in existing regulations at the national and international levels. However, numerous challenges stand between augmented legal regulations and the alleviation of social crises (Aguirre, 2011; Mayer, 2011; McCorquodale, 2009). The solution lies not in greater control but a new approach to global corporate citizenship, whereby socially responsible organizations achieve profit through pursuing ethical goals (Scheffer \& Kaeb, 2011; TED, 2013).

We begin with a brief discussion of the relationship between law, economics, and sustainability. Next, we examine the impact of this relationship using key examples from the pharmaceutical and information industries. Finally, we conclude with specific suggestions for future research.

\section{Law, Economics, and Sustainability}

The relationship between free-market economic policies and social rights is now at the center of an intense debate. According to Adam Smith, individuals succeed through hard work, determination, and maximizing selfinterest to the point of greed (Wang \& Murnighan, 2011). However, George (2014) asserted that capitalistic values based on the yearning for monetary success conflict with the ethical and social principles that are essential to the operation of society. The wealthiest $1 \%$ of Americans own approximately $40 \%$ of the country's wealth (Jilani, 2011). The lowest $80 \%$ of Americans possess only $7 \%$ of the nation's wealth (Lazonick, 2010). Massive wealth and convoluted legal regulations enable corporations to influence governmental oversight, eliminate competition, and control market prices (Gopnik, 2010); thus, supporting the contention that free-market ideologies are contrary to widespread social value (George, 2014; Mattick, 2011). 
Due to the perceived shortcomings of free-market capitalism, scholars are increasingly exploring the benefits of alternative economic models. According to George (2014), increased regulation partially drives the success of alternative economic models. In the emerging market economies of Brazil, Russia, India, China, and South Africa (BRICS), national governments utilize regulatory tools to assume a more direct role in economic development (McNally, 2013). However, the recent human rights records in these countries (Human Rights Watch, 2014), demonstrate that increased legal regulation alone cannot effectively alleviate social crises (Mattick, 2011). In fact, specific legal regulations increase social harm through the preservation of corporate economic interests. For example, on the one hand intellectual property law safeguards patent ownership over genetically modified foods. On the other hand, global hunger is growing at an exponential rate, as over 800 million of the world's inhabitants lack the food necessary for healthy living (Food and Agriculture Organization of the United Nations, 2014). In the aftermath of Hurricane Katrina, the drive for crop-based fuels in the United States tripled the price of wheat, rice, corn, and soybeans. Brown (2009) questioned whether it is ethical to place control over the items essential to human life into the hands of the few.

As noted by Mayer (2011), an examination of the law is critical in terms of the ability to sustain economic activities that do not harm people or the planet. Transnational corporations (TNCs) wield unprecedented power and influence across the globe (Macklem, 2005). As early as 2001, 500 of the world's largest companies boasted annual sales greater than the GNP of 100 of the world's nations (Johnson \& Turner, 2010). Corporations are critical participants in economic activities that affect water sources, aquifers, forests, fisheries, and the planet (Mayer, 2011). Although TNCs support global human rights through the advancement of living standards and job creation (Bradford, 2012), these organizations also inflict collateral damage on people, communities, and the environment (Chandler, 2006). Oil exploration companies recently faced accusations of crimes against humanity, arbitrary arrest, and torture of Nigerian citizens (Kiobel v. Royal Dutch Petroleum Company, 2013). Regrettably, corporations are not legally bound to respect social or human rights under international law (Muchlinksi, 2012).

Attempts to reduce the negative impact of corporate activities on social and human rights have faced many challenges. According to McCorquodale (2009), efforts to curb TNC human rights violations often fail due to suspicious oversight by foreign governments. Human rights advocates recently accused the Zambian government of poorly enforcing labor laws and mining regulations to solicit foreign direct investment from Chinese copper mining companies (Human Rights Watch, 2012). Similarly, Australian-based BHP Corporation reportedly wielded such a strong influence over the government of Papua New Guinea through the enactment of laws to protect the company from legal liability (McCorquodale, 2009). As noted by Aguirre (2011, p. 125), this dilemma forced the international community to ask, "How can responsibility be extended to hundreds of thousands of TNCs if states and are increasingly unwilling and unable to regulate them?"

The dynamics of resource scarcity further compound the difficulties surrounding the regulation of global corporations. According to Brown (2009), ecological and social collapses have reinforced a downward spiral of poverty, social injustice, disease, and violence. In 2007, experts projected that 1.7 billion people lacked access to vital medicines (National Board of Trade, 2008). By 2014, projections rose to nearly 2 billion people (Access to Medicine Foundation, 2014). Of the 14 million people killed each year by infectious diseases, $90 \%$ live in the developing world (Khoury, 2008). Although $21 \%$ of all global disease comes from malaria, pneumonia, diarrhea, and tuberculosis, these illnesses receive less than $1 \%$ of all private investments (Zolotaryova, 2008). Consequently, these disheartening figures enhance the argument that pharmaceutical companies must suspend drug patent rights that conflict with severe global health issues (Feldman, 2009).

\section{Patents and the Pharmaceutical Industry}

Despite the strong protections provided by patent laws, patent holder rights are not absolute. To address ongoing global health concerns, the World Trade Organization (WTO) (2015) enacted the Agreement on TradeRelated Aspects of Intellectual Property Rights (TRIPS). Under TRIPS, WTO member nations have the discretion to issue compulsory licenses for pharmaceutical patents in cases of national emergency (World Trade Organization, 2015). Such licenses enable third parties to produce patented drugs without the permission of the patent holders (Cahoy, 2007). Public health crises, such as HIV/AIDS, tuberculosis, and malaria, can constitute national emergencies (World Health Organization, 2015). 
Concerns over the potential misuse of compulsory licenses by national governments provoked concern and criticism from the pharmaceutical industry. Research and development are costly and risky processes. Prospective profits are a necessary incentive for encouraging the invention of marketable products (Greve, 2008). Pharmaceutical companies rely on patents to recoup the high costs associated with the creation of new drugs (Congress of the United States Congressional Budget Office, 2006). Health experts expressed concerns that nonessential uses of compulsory licenses would discourage pharmaceutical research (Khoury, 2008), reduce medical progress and innovation (Greve, 2008), and lead to a decline in global health (Feldman, 2009).

Despite the misgivings of the pharmaceutical industry, TRIPS did not result in the widespread misuse of compulsory licenses for pharmaceutical patents. Beall and Kuhn (2012) conducted a systematic analysis of compulsory license activity, identifying 24 episodes in 17 nations between 1995 and 2011 . Only 50\% of all the cases examined ended with the announcement of a compulsory license. Beall and Kuhn (2012) maintained that TRIPS had a negligible long-term impact on the regular use of compulsory licenses and a negligible impact on global access to pharmaceuticals. Scholars have offered many explanations to support these results. The overuse of compulsory licenses could provoke retaliatory market withdrawal by drug producers, informal pressure on foreign trade, or official action by the WTO (Smith, Correa, \& Oh, 2009). However, Beall and Kuhn (2008) argued that the insignificant rise in compulsory licenses reflects recent efforts to increase pharmaceutical access in the poorest countries.

Pharmaceutical companies are doing more to promote corporate social responsibility in recent years. According to the Access to Medicine Foundation (2014), the top 20 research-based pharmaceutical companies are undertaking more innovations and initiatives to improve medical access in developing countries. Over the last several years, pharmaceutical companies have agreed increasingly to more progressive licensing arrangements. GlaxoSmithKline (GSK) has issued voluntary licenses for drugs targeting lower respiratory tract infections, measles, mumps, and rubella. Similarly, Bristol-Myers Squibb pledged the company would not enforce certain patents in select countries. Out of the 16 companies in a position to issue voluntary licenses, eight are doing so (Access to Medicine Foundation, 2014). The examples above provide encouragement for the future role of business in solving social problems.

\section{A New Era for Socially Conscious Organizations}

Without active participation from the business community, global responsibility and sustainability efforts cannot succeed (Mayer, 2011). In his TED (2013) Talk, Michael Porter of Harvard Business School scrutinized the role of business in a global economy filled with diverse social issues. Porter challenged the conventional notion that companies can only profit by causing social problems, arguing instead that companies can profit from solving social problems. To support his proposition, Porter suggested that through the capitalism of meeting essential needs, corporate leaders could change the perception of the business community perceives among leaders, and how the public perceives the business community (TED, 2013).

The case of Google in China is an example of how organizations can implement the concepts described in Porter's TED (2013) Talk. In late 2009, Google was the victim of a cyber-attack. Based on available evidence, Google suspected the attack was an attempt by the Chinese government to access the Gmail accounts of Chinese human rights activists (Drummond, 2010). When negotiations with Chinese officials proved unsuccessful, Google shut down its site in China (Whetstone, 2010). Reacting to this decision, Scheffer \& Kaeb (2011, p. 382) pose a fundamental question, "What motivated Google to pull out of one of the largest future markets with a prospect of more than 800 million Internet users over the next 10 years?" In describing the motivations behind Google's decision, Whetstone (2010, para. 6) noted, “. . . we don't want to engage in political censorship. This is especially true in countries like China and Vietnam that do not have democratic processes through which citizens can challenge censorship mandates." In a response to their own query, Scheffer \& Kaeb (2011) suggest that Google's actions in China demonstrate how compliance with social and human rights can be a market incentive and a central part of an organization's strategy. Google's experience in China is a powerful illustration how socially responsible organizations seek ethical objectives enabled by profit. Scheffer and Kaeb (2011) suggested that Google's actions in China demonstrate how compliance with social and human rights can be a market incentive and a central part of an 
organization's strategy. Google's experience in China is a powerful illustration how socially responsible organizations seek ethical objectives enabled by profit.

\section{CONCLUSION}

The shifting relations between law, economics, and sustainability have profoundly affected the social consciousness of the global business community. Due to the rise in CSR, there is greater corporate recognition of the connection between social consciousness and profit (Singh, Iglesias, \& Batista-Foguet, 2012). The corporative pursuit of profits with societal advantages is vital to sustaining the fiduciary duties and values mandate by global CSR (Blodgett, Hoitash, \& Markelevich, 2014). Although further regulation may alleviate the contentions of profit over ethics, a more revolutionary approach to corporate responsibility is necessary and achievable. In this article, we have aligned research that demonstrates linkages among the factors of law, economics and sustainability. Through the pursuit of a more socially conscious corporate strategy, companies can advance the agendas of global social responsibility while fostering sustainability in this process. Future research may track the activities of TNCs where social and human rights are central components of overall organizational strategy. Identification and review of such firms will further solidify the links between profit, social responsibility, and corporate strategic objectives.

\section{ACKNOWLEDGEMENTS}

The authors wish to thank Dr. Julie Conzelmann, CCE and Mr. John Oziem for their editorial assistance.

\section{AUTHOR INFORMATION}

Evan A. Peterson is a licensed attorney, Lecturer in Business Law, and Director of Undergraduate Business Programs in the College of Business Administration. His research activities have included publication on diverse topics related to business law, ethics, and sustainability. Evan A. Peterson (contact author), Lecturer in Business Law, College of Business Administration, University of Detroit Mercy, 4001 W. McNichols Road, Detroit, MI 48221 USA. Email: petersea@udmercy.edu

Carletta E. Griffin is an adjunct professor in the College of Business Administration. Dr. Griffin holds a Doctorate of Management with a specialization in organizational leadership. Her research interests include social entrepreneurship, social change within organizations, and the role of faith-based organizations in transforming challenged urban communities. Dr. Griffin is CEO of a national disability advocacy practice and is passionate about serving in her local community. Carletta E. Griffin, Adjunct Professor, College of Business Administration, University of Detroit Mercy, USA. Email: carlettagriffin@msn.com

Gregory W. Ulferts is a Professor of Decision and Systems Sciences in the College of Business Administration. His scholarly activities have included research and publication on various topics related to management information systems, financial management, decision sciences, small business administration, and international business. Dr. Ulferts has served as a consultant to business and government in areas such as strategic and technology planning, operations and procurement management, analysis and design of systems, and business development. Gregory W. Ulferts, Professor of Decision Sciences, College of Business Administration, University of Detroit Mercy, USA. Email: ulfertgw@udmercy.edu

Terry L. Howard is a Lecturer of Decision and Systems Sciences in the College of Business Administration. He works with Business Leadership Network of Michigan and serves as the Director of the Leadership and Economic Independence program, working with individuals with challenges. Mr. Howard has published papers nationally in professional and academic journals. Terry L. Howard, Lecturer in Decision Sciences, College of Business Administration, University of Detroit Mercy, USA. Email: howardt1@udmercy.edu 


\section{REFERENCES}

Access to Medicine Foundation. (2014, November). Access to medicine index 2014. Retrieved from http://www.accesstomedicineindex.org/sites/2015.atmindex.org/files/2014_accesstomedicineindex_fullrepo rt_clickablepdf.pdf

Aguirre, D. (2011). Corporate liability for economic, social and cultural rights revisited: The failure of international cooperation. California Western International Law Journal, 42, 124-148.

Beall, R., \& Kuhn, R. (2012). Trends in compulsory licensing of pharmaceuticals since the Doha Declaration: a database analysis. PLoS medicine, 9(1), e1001154. doi:10.1371/journal.pmed.1001154

Blodgett, M. S., Hoitash, R., \& Markelevich, A. (2014). Sustaining the financial value of global CSR: Reconciling corporate and stakeholder interests in a less regulated environment. Business \& Society Review, 119(1), 95124. doi:10.1111/basr.12026

Bradford, W. (2012). Beyond good and evil: the commensurability of corporate profits and human rights. Notre Dame JL Ethics \& Pub. Pol'y, 26, 141. doi:10.2139/ssrn.991241

Brown, L. R. (2009). Plan B 4.0: Mobilizing earth to save civilization. New York, NY: W.W. Norton \& Company.

Cahoy, D. R. (2007). Confronting myths and myopia on the road from Doha. Georgia Law Review, 42, 08.

Chandler, G. (2006). Corporate liability: Human rights and modern business. Keynote address presented at JUSTICE and Sweet \& Maxwell conference. Retrieved from http://business-humanrights.org/en/keynoteaddress-by-sir-geoffrey-chandler-at-justice-and-sweet-maxwell-conference-corporate-liability-humanrights-and-the-modern-business-12-june-2006

Congress of the United States Congressional Budget Office. (2006). Research and development in the pharmaceutical industry. Retrieved from http://www.cbo.gov/sites/ default/files/ cbofiles/ftpdocs/76xx/doc7615/10-02-drugr-d.pdf

Drummond, D. (2010, January 12). A new approach to China [Web log post]. Retrieved from http://googleblog.blogspot.com/2010/01/new-approach-to-china.html

Feldman, J. (2009). Compulsory licenses: the dangers behind the current practice. Journal of International Business \& Law, 8(1)(9), 137. Retrieved from http://scholarlycommons.law.hofstra.edu/jibl/vol8/iss1/9

Food and Agriculture Organization of the United Nations. (2014). The state of food insecurity in the world 2014. Retrieved from http://www.fao.org/3/a-i4030e.pdf

George, J. M. (2014). Compassion and capitalism: Implications for organizational studies. Journal of Management, 40(5), 5-14. doi:10.1177/0149206313490028

Gopnik, A. (2010, October 18). Market man: What did Adam Smith really believe? The New Yorker, 86(32), 82-87.

Greve, J. (2008). Healthcare in developing countries and the role of business: a global governance framework to enhance the accountability of pharmaceutical companies. Corporate Governance: The international journal of business in society, 8(4), 490-505. doi:10.1108/14720700810899220

Human Rights Watch. (2012). China: CNMC public listing needs investor vigilance mining firm 's labor record in Zambia a red flag. Retrieved from http://www.hrw.org/news/ 2012/04/22/china-cnmc-public-listing-needsinvestor-vigilance

Human Rights Watch. (2014). World report 2014. Retrieved from http://www.hrw.org/sites/default/files/ wr2014_web_0.pdf

Jilani, Z. (2011). How unequal we are: The top 5 facts you should know about the wealthiest one percent of Americans. Retrieved from http://thinkprogress.org/economy/2011/10/03/334156/top-five-wealthiest-onepercent/

Johnson, D., \& Turner, C. (2010). International Business: Themes and issues in the modern global economy. Routledge.

Kiobel v. Royal Dutch Petroleum, 133 S.Ct. 1659 (2013). Retrieved from http://caselaw.findlaw.com/summary/ opinion/us-supreme-court/2013/04/17/264279.html

Khoury, A. H. (2008). The 'public health' of the conventional international patent regime \& the ethics of 'ethicals': Access to patented medicines. Cardozo Arts \& Entertainment Law Journal, 26, 25.

Lazonick, W. (2010). Innovative business models and varieties of capitalism: Financialization of the U.S. corporation. Business History Review, 84, 675-702. doi:10.1017/s0007680500001987

Macklem, P. (2005, January). Corporate accountability under international law: The misguided quest for universal jurisdiction. In International Law FORUM du droit international, 7(4), 289. doi:10.1163/ 157180405775268356 
Mattick, P. (2011, March 13). Capitalism's dismal future. The Chronicle of Higher Education 57(28), B8-B10.

Mayer, D. (2011). Legal loopholes, business ethics, and corporate legal strategy: A reply to professor Ostas. American Business Law Journal, 48(4), 713-763. doi:10.1111/j.1744-1714.2011.01123.x

McCorquodale, R. (2009). Corporate social responsibility and international human rights law. Journal of Business Ethics, 87, 385-400. doi: 10.1007/s10551-009-0296-5

National Board of Trade. (2008). The WTO decision on compulsory licensing. Retrieved from http://www.kommers.se/Documents/dokumentarkiv/publikationer/2008/rapporter/report-the-wto-decisionon-compulsory-licensing.pdf

Scheffer, D. \& Kaeb, C. (2011). The five levels of CSR compliance: The resiliency of corporate liability under the Alien Tort Statute and the case for a counterattack strategy in compliance theory. Berkeley Journal of International Law, 29, 334-397.

Singh, J., Iglesias, O., \& Batista-Foguet, J. (2012). Does having an ethical brand matter? The influence of consumer perceived ethicality on trust, affect and loyalty. Journal of Business Ethics, 111(4), 541-549. doi:10.1007/s10551-012-1216-7

Smith, R. D., Correa, C., \& Oh, C. (2009). Trade, TRIPs, and pharmaceuticals. Lancet, 373(9664), 684-691. TED (Producer). (2013). Michael Porter: Why business can be good at solving social problems [Video file]. Retrieved from http://www.ted.com/talks/michael_porter_why_business_can_be_good_at_ solving_social_problems.html

Wang, L., \& Murnighan, J. K. (2011). On greed. The Academy of Management Annals, 5(1), 279-316.

Whetstone, R. (2010, April 19). Controversial content and free expression on the web: a refresher [Web log post]. Retrieved from http:/googleblog.blogspot.com/2010/04/ controversial-content-and-free.html

World Health Organization. (2015). The Doha Declaration on the TRIPS agreement and public health. Retrieved from http://www.who.int/medicines/areas/policy/doha_declaration/en/

World Trade Organization. (2015). Overview: the TRIPS agreement. Retrieved from https://www.wto.org/english/tratop_e/trips_e/intel2_e.htm

Zolotaryova, V. (2008). Are we there yet-Taking TRIPS to Brazil and expanding access to HIV/AIDS medication. Brooklyn Journal of International Law, 33(1), 1099-1125. 